\title{
Bean common mosaic virus and Bean common mosaic necrosis virus in Mexico
}

N. Flores-Estévez, Department of Plant Genetic Engineering, CINVESTAV-IPN, Irapuato, Gto, Mexico; J. A. Acosta-Gallegos, Bean Program, INIFAP, Celaya, Gto, Mexico; and L. Silva-Rosales, Department of Plant Genetic Engineering, CINVESTAV-IPN

\begin{abstract}
Flores-Estévez, N., Acosta-Gallegos, J. A., and Silva-Rosales, L. 2003. Bean common mosaic virus and Bean common mosaic necrosis virus in Mexico. Plant Dis. 87:21-25.

A survey was performed in Mexico to study the distribution of Bean common mosaic virus (BCMV) and Bean common mosaic necrosis virus (BCMNV) using a set of primers directed to the coat protein gene $(\mathrm{CP})$ that were designed to detect and characterize the two viral species. Both viral species were present in different locations in the country. BCMV was predominant in the central states of the country, whereas BCMNV proliferated toward the eastern tropical states. The alignment of nine nucleotide sequences for each viral species at the amino region of the $\mathrm{CP}$ gene confirmed the identities of the viruses and set the basis to assign them tentatively to pathogroups I, II, and VI.
\end{abstract}

Additional keywords: bean mosaic, black root, potyvirus, systemic necrosis

Bean common mosaic virus (BCMV) and Bean common mosaic necrosis virus (BCMNV) are closely related pathogens of the common bean, Phaseolus vulgaris. Until 1992, these viruses were considered as serotypes $\mathrm{B}$ and $\mathrm{A}$, respectively, of the same virus in the BCMV species. They then were reclassified as two separate viral species on the basis of multiple properties (4). These included the peptide profiles of their coat protein (CP) (19), their cytological effects in infected tissue, estimations of their CP molecular weight, the amino acid sequence of the N-terminus of the CP (27), and their serological relationships (20). They are now two species and are members of the genus Potyvirus of the family Potyviridae (8). Particles of these viruses are flexible rods, about $750 \mathrm{~nm}$ long and $14 \mathrm{~nm}$ wide, composed of a single-stranded RNA genome with a VPg protein covalently linked to its $5^{\prime}$ end and encapsulated in about 2,000 monomer units of 30$\mathrm{kDa} \mathrm{CP}$. The organization of the BCMNV genome, based on the only available fulllength nucleotide sequence (10) and that of other similar potyviruses, consists of two short, untranslatable sequences at the $5^{\prime}$ and 3 ' ends, and a single, long open reading frame (ORF). The ORF is translated into a polyprotein which is processed into

Corresponding author: L. Silva-Roasles E-mail: 1silva@irapuato.ira.cinvestav.mx

This research was funded in part by CONACyT (Mexico) with a doctoral fellowship (no. 113740) to Norma Flores-Estévez.

Accepted for publication 14 August 2002.

Publication no. D-2002-1111-02R

(C) 2003 The American Phytopathological Society nine proteins as follows: proteinase 1 (Pro 1); helper component-proteinase (HC-Pro); proteinase 3 (Pro 3); a 6-kDa protein; cylindrical inclusion (CI); a second 6-kDa protein product; nuclear inclusion " $\mathrm{a}$ " (NIa); nuclear inclusion " $b$ " (NIb); and CP. There is, as yet, no thorough description of the protein products of the genome of BCMV but, according to the genomic organization of many other potyviruses, it is probably very similar to that of BCMNV $(1,9)$.

Both BCMV and BCMNV produce very similar symptoms in bean plants-mostly mosaic, dwarfing, leaf curling, and chlorosis. Another syndrome, "systemic necrosis", "top necrosis" (15), or " black root" (26), which consists of systemic necrosis and typically leads to plant death, can be caused either by BCMNV (at all temperatures) or necrosis by strains of BCMV (at higher temperatures). This syndrome is the result of the induction of a "hypersensitive response" (HR), more appropriately called a "spreading vascular necrosis" (6), associated with the presence of the dominant $I$ gene in a given bean cultivar (15). This gene conditions monogenic resistance to strains of BCMV. However, when the plant is challenged with BCMV strains at temperatures above $30^{\circ} \mathrm{C}$ (temperaturedependent) or with BCMNV at any temperature (temperature-independent), systemic top necrosis and plant death are induced. (15). It is not surprising, therefore, that the similarity of symptoms produced by some strains of both viruses makes it very difficult to distinguish them in the field (22).

It has been reported that BCMV and BCMNV are not equally distributed in the bean production areas of the world (22). For instance, in northern Central America, the center of origin and diversity of $P$. vulgaris, strain US1 of BCMV has been reported as predominant and strain NL3 of BCMNV has a lower incidence (4). However, the overall frequency and distribution of BCMV and BCMNV are not clear, given the paucity of pertinent distribution data from many countries in this and many other areas, as well as the similar field behavior of the two viruses. Mexico, where the bean crop is widely distributed, is no exception in this respect; earlier reports make reference to the presence of BCMV only in the federal states of Puebla (7), Guanajuato (21), Veracruz (18), and Sonora (14). The most important commercial bean-producing area in Mexico is located in a semiarid region contained, from south to north, in the states of Zacatecas, Durango, and Chihuahua (3). There are no published reports available about the presence of disease caused by these viruses in these areas. The rest of the country is littered with small bean production areas (for self-consumption) and epidemiological data for BCMV is virtually nonexistent. Both BCMV and BCMNV are transmitted through seed; therefore, the traditional sowing of seed obtained from the previous harvest, regional seed exchange. and imports from other countries should have an impact on the distribution and diversity of both viruses in Mexico. A study of the presence and diversity of these viruses in most bean-growing regions of Mexico has been initiated in order to establish which species are predominant and how they relate to each other on the basis of comparisons of their $\mathrm{CP}$ nucleotides and predicted amino acid sequences. A reverse transcription-polymerase chain reaction (RT-PCR) procedure was set up to amplify the $\mathrm{CP}$ gene of each virus. The nucleotide sequences were determined and analyses of these and other published sequences were conducted. An association of certain domains within the amino-terminal region of the CP to specific pathogroups in the two viral species was found. Based on this, pathogroups (12) within the BCMV and BCMNV species of the Mexican isolates were tentatively assigned.

\section{MATERIALS AND METHODS}

Biological material. Tissue samples and seeds of Phaseolus vulgaris L. were randomly collected in 16 federal states of Mexico corresponding to three different ecogeographical regions: semiarid highlands (Chihuahua, Durango, Zacatecas, and 
San Luis Potosí), where mostly pinto, shiny black, and cream (bayo) seeded cultivars are produced and consumed; semihumid temperate highlands (Mexico Guanajuato, Jalisco, Hidalgo, and Tlaxcala), where several cultivars with different seed coat colors (Flor de mayo, shiny black, bayo, pink, and so on) are grown; and humid tropical lowland and midland regions (Puebla, Veracruz, Tabasco, Chiapas, Campeche, and Quintana Roo), where mostly opaque black-seeded cultivars are grown (23) (Fig. 1). The sampled areas were from either experimental stations or large and small producers.

Imunodetection of BCMV. Initially, western-blot analysis (17) was carried out using commercial polyclonal antibodies (Agdia, Elkhart, IN) against BCMV to identify this viral species.

RT and PCR, cloning, and sequencing. Total RNA from mature leaves from field plants was extracted using a method published previously (24). Three primers were designed to reverse transcribe and amplify the $\mathrm{CP}$ gene of both virus species: a common primer complementary to the $3^{\prime}$ end and one specific $5^{\prime}$ primer for each virus. The design of the primers was based on three sequences available in GenBank: (L11890 and U55315 for BCMV and U19287 for BCMNV) and on a strategy reported previously (25).

RT reactions were carried out using $4 \mu \mathrm{g}$ of total extracted RNA and 15 pmol of the $3^{\prime}$ primer in a volume of $17.5 \mu \mathrm{l}$. RNA and primer, in a volume of $15 \mu \mathrm{l}$, were denatured at $70^{\circ} \mathrm{C}$ for $10 \mathrm{~min}$ and mixed with 5 $\mu \mathrm{l}$ of $5 \times$ RT-Buffer (Promega Corp., Madison, WI); $10 \mathrm{U}$ of M-MLV (Promega
Corp.); $2.5 \mathrm{mM}$ each of dGTP, dCTP, dTTP, and dATP; and $\mathrm{H}_{2} \mathrm{O}$ for a final reaction volume of $25 \mu \mathrm{l}$. The mixture was incubated at $42^{\circ} \mathrm{C}$ for $30 \mathrm{~min}$. Two sets of RT reactions were used in separate PCRs, each with one of the $5^{\prime}$ primers specific for BCMNV or BMCV (Fig. 2). The PCR mixture was set up with $10 \mu$ of the RT reaction, $5 \mu \mathrm{l}$ of $10 \times$ PCR buffer (BRLGibco, Acceslab, Mexico City), $1 \mu$ l of 50 $\mathrm{mM} \mathrm{MgCl}_{2}, 2.5 \mathrm{U}$ of $\mathrm{Taq}$ polymerase

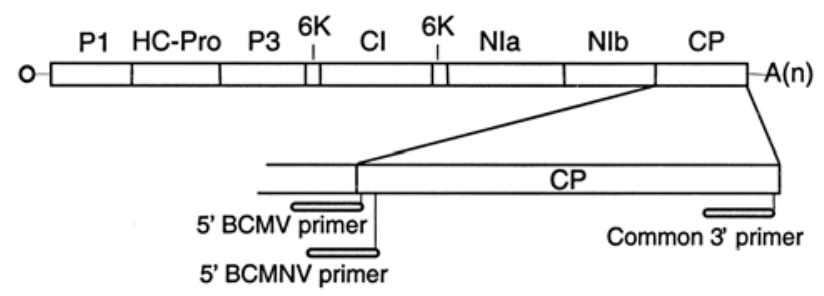

Fig. 2. Schematic representation of the genome organization of Bean common mosaic virus (BCMV) subgroup. Thin line and open circle on the left represent the $5^{\prime}$ untranslated region (UTR) with the VPg (virus protein genome linked), respectively. Large open box represents the viral polyprotein with the following proteins: P1 (proteinase 1), HC-Pro (helper component-proteinase), P3 (proteinase 3 ), 6k, CI (cylindrical inclusion), 6k, NIa (nuclear inclusion protein "a"), NIb (nuclear inclusion protein "b"), and CP (capsid protein). The thin line to the right represents the $3^{\prime}$ UTR with a poly A tail: A(n). Positions of the common and specific primers used to amplify the CP gene for BCMV and $\mathrm{BCMNV}$ are indicated as thin bullets in the enlarged representation of the CP.

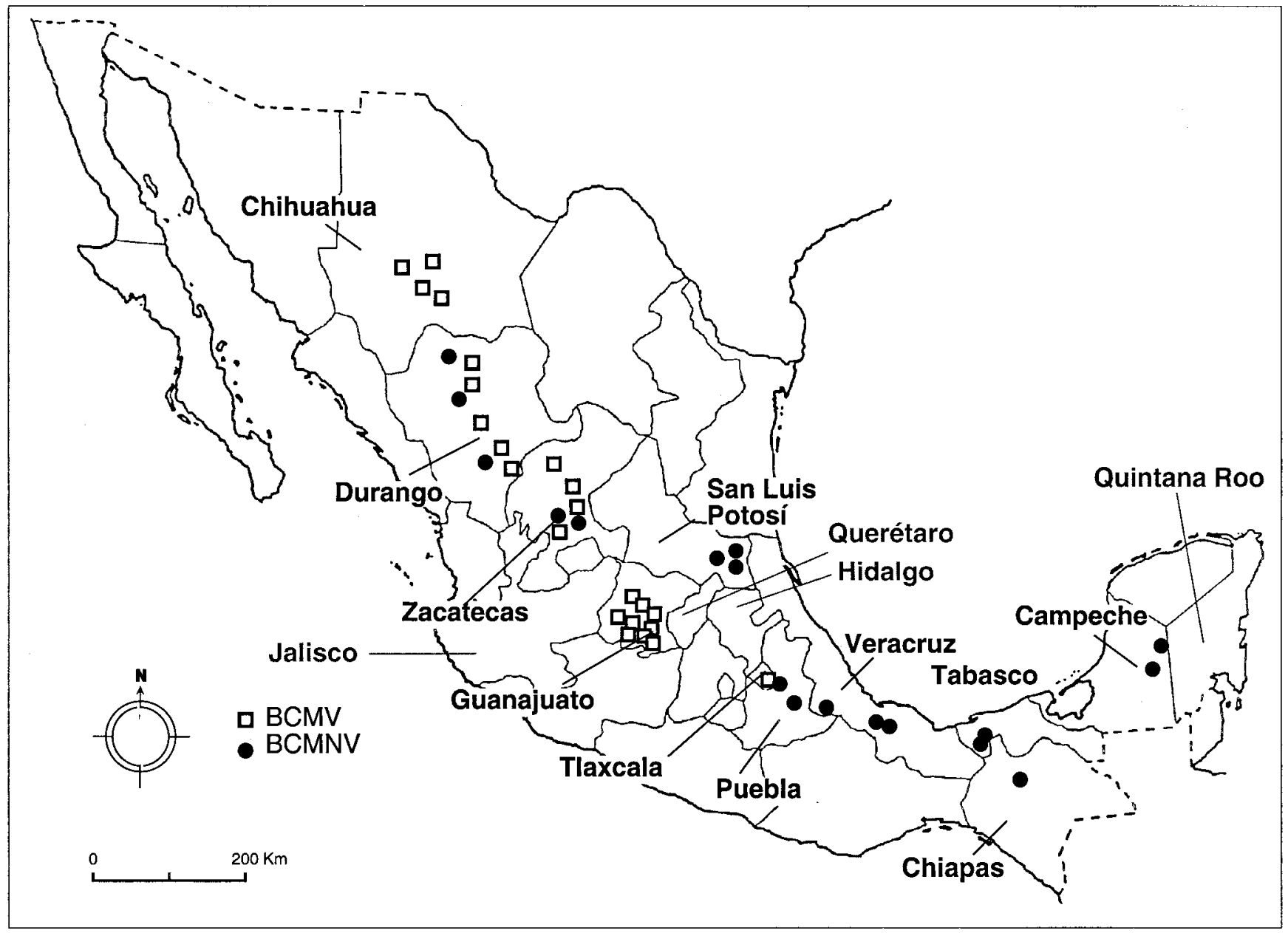

Fig. 1. Geographic distribution of Bean common mosaic virus (BCMV) and Bean common mosaic necrosis virus (BCMNV) in Mexico, according to the diagnosis by reverse transcription-polymerase chain reaction using specifically designed primers for each viral species. 
(BRL-Gibco), water, and 10 pmol of differential $5^{\prime}$ primer in a final volume of $50 \mu \mathrm{l}$. Reactions were performed in a GeneAmp PCR system 2400 thermocycler (Applied Biosystems, Foster City, CA) with the following program: 1 cycle, $5 \mathrm{~min}$ at $90^{\circ} \mathrm{C} ; 25$ cycles, each including $1 \mathrm{~min}$ at $90^{\circ} \mathrm{C}, 1 \mathrm{~min}$ at $64^{\circ} \mathrm{C}$, and $30 \mathrm{~s}$ at $72^{\circ} \mathrm{C}$; and a final cycle at $72^{\circ} \mathrm{C}$ for $7 \mathrm{~min}$. Positive controls for RT-PCR reactions of each viral species were included: the NL1 strain for BCMV and two, previously cloned and sequenced Mexican BCMNV strains (11).

To confirm the identity of the amplified products, 18 selected RT-PCR products (9 each of BCMV and BCMNV; Table 1) were cloned using the TOPO TA cloning kit, containing the vector pCR 2.1 (Invitrogen, Carlsbad, CA), and sequenced in an ABI 373A automatic sequencer (Applied Biosystems).

The nucleotide and deduced amino acid sequences were compared with those in GenBank using the BLAST (2) facility at the National Center for Biotechnology Information website. They also were analyzed using the Clustal method of the LaserGene software (DNASTAR, Madison, WI), or with Clustal X (version 1.8.1; 13). Sequences of BCMV from other parts of the world were obtained from GenBank with the following accession numbers: L15332 (NL1; 4), SS6251 (NL1; 8), U37074 (US4), U55316 (Mexican), U55319 (US1), U55317 (NL7), L19473 (US5), L19472 (NL2), U55319 (Type), U55315 (Florida), U37037 (US3), US5318
(NY15), and L21766 (NL4). The two sequences for BCMNV available in GenBank had accession numbers U19287 (NL3) and U37076 (TN1). The amino acid sequence corresponding to isolate NL8 was obtained from published results (27).

\section{RESULTS}

Presence of BCMV and BCMNV in Mexico. All 79 collected samples were subjected to RT-PCR to amplify the nucleotide sequence corresponding to the $\mathrm{CP}$ protein from both BCMV and BCMNV. Forty-six samples gave positive results for one or both viruses (Table 1). A slight difference in the size of the amplified gene segment between the two viral species, due to the position of the $5^{\prime}$ primers (Fig. 2) and the difference in size of the corresponding $\mathrm{CP}$ gene, allowed their accurate distinction (Fig. 3). In all, 29 leaf samples tested positive for the presence of BCMV, confirming preliminary results obtained using commercial antibodies; 21 tested positive for the presence of BCMNV (Table 1); and 33 tested negative for both viruses. No BCMV- or BCMNV-positive samples were collected from the states of

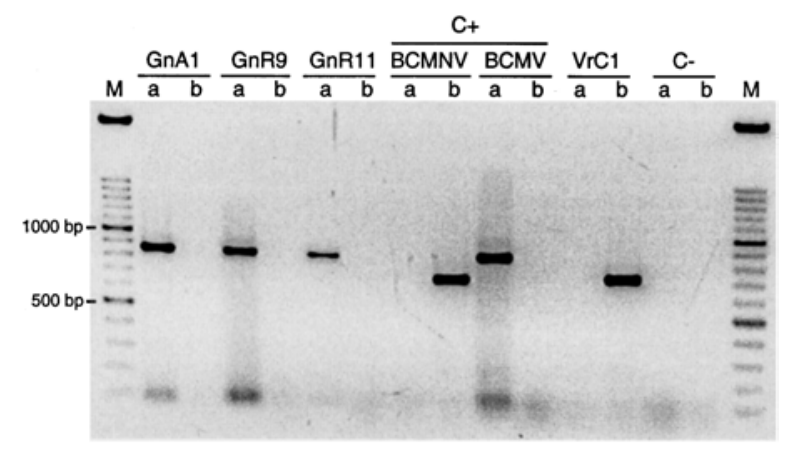

Fig. 3. Examples of reverse transcription-polymerase chain reaction products of most of the capsid protein (CP) genes of Bean common mosaic virus (BCMV) and of Bean common mosaic necrosis virus (BCMNV), after electrophoretic separation in a 1.5\% agarose gel. Lanes "a" contain 890-bp products after amplification with the 5' primer for BCMV. Lanes "b" contain 740-bp fragments after amplification with the 5' primer for BCMNV. GnA1, GnR9, and GnR11 are Guanajuato isolates, and $\mathrm{VrCl}$ is a Veracruz isolate. Positive controls $(\mathrm{C}+)$ were established with isolates from Aguascalientes for BCMNV and with the NL1 strain for BCMV. The negative control $(\mathrm{C}-)$ was obtained from healthy bean leaf tissue. Molecular weight marker bands (M) are indicated in base pairs in the left margin.

Table 1. Locations of collected samples, results of the diagnosis of the viral species present, and accession numbers of the cloned samples

\begin{tabular}{|c|c|c|c|c|c|c|c|}
\hline \multirow[b]{2}{*}{ Field isolate number ${ }^{\mathrm{c}}$} & \multicolumn{2}{|c|}{ Origin } & \multirow[b]{2}{*}{ Samples collected } & \multicolumn{2}{|c|}{ RT-PCR, positive ${ }^{a}$} & \multicolumn{2}{|c|}{ Cloned isolates $^{b}$} \\
\hline & State & Location & & BCMV & BCMNV & BCMV & BCMNV \\
\hline 1 & Puebla & Palmarito & 2 & $\ldots$ & 1 & NA & PbP84 \\
\hline 2,3 & Campeche & Hopelchén & 2 & $\ldots$ & 2 & NA & $\mathrm{CmH} 8$ \\
\hline 4,5 & Chiapas & Pantepec & 2 & $\ldots$ & 2 & NA & $\mathrm{CpP} 52^{\mathrm{d}}$ \\
\hline 6 & Chihuahua & General Trías & 1 & 1 & $\ldots$ & $\mathrm{NC}$ & NA \\
\hline 7 & & Gran Morelos & 1 & 1 & $\ldots$ & $\mathrm{ChGM} 24^{\mathrm{d}}$ & NA \\
\hline 8 & & Cuauhtémoc & 2 & 1 & $\ldots$ & $\mathrm{ChC} 25^{\mathrm{d}}$ & NA \\
\hline 9 & Durango & Vicente Guerrero & 1 & 1 & $\ldots$ & $\mathrm{NC}$ & NA \\
\hline 10,11 & & Villa Ocampo & 1 & 1 & 1 & DrVO4$^{d}$ & $\mathrm{NC}$ \\
\hline 12 & & Las Nieves & 1 & 1 & $\ldots$ & $\mathrm{NC}$ & NA \\
\hline 13,14 & & Madero & 1 & 1 & 1 & $\mathrm{NC}$ & $\mathrm{NC}$ \\
\hline 15,16 & & Durango & 1 & 1 & 1 & DrD37 & $\mathrm{DrD}^{\mathrm{d}}$ \\
\hline 17,18 & Guanajuato & Abasolo & 2 & 2 & $\ldots$ & $\mathrm{GnA} 1^{\mathrm{d}}$ & NA \\
\hline $19,20,21,22,23$ & & Las Masas & 5 & 5 & $\ldots$ & $\mathrm{NC}$ & NA \\
\hline $24,25,26$ & & Irapuato & 3 & 3 & $\ldots$ & $\mathrm{NC}$ & NA \\
\hline $27,28,29,30,31$ & & Romita & 5 & 5 & $\ldots$ & GnR9 $9^{d}$ GnR $11^{d}$ & NA \\
\hline 32 & & Gavia de Rivas & 1 & 1 & $\ldots$ & $\mathrm{NC}$ & NA \\
\hline $33,34,35$ & San Luís Potosí & Tamuín & 3 & $\ldots$ & 3 & NA & $\mathrm{SpT}^{\mathrm{d}}$ \\
\hline 36,37 & Tabasco & Huimanguillo & 2 & $\ldots$ & 2 & NA & TbH22 \\
\hline $38,39,40$ & Tlaxcala & Tenancingo & 2 & 1 & 2 & TlT93 $^{\mathrm{d}}$ & $\mathrm{NC}$ \\
\hline 41,42 & Veracruz & Cosamaloapan & 2 & $\ldots$ & 2 & NA & $\mathrm{VrC1}$ \\
\hline 43,44 & & Maltrata & 2 & $\ldots$ & 2 & NA & $\mathrm{NC}$ \\
\hline $45,46,47$ & Zacatecas & Fresnillo & 2 & 2 & 1 & $\mathrm{NC}$ & $\mathrm{ZcF}^{\mathrm{d}}$ \\
\hline 48 & & Sombrerete & 1 & 1 & $\ldots$ & $\mathrm{NC}$ & NA \\
\hline 49,50 & & Zacatecas & 1 & 1 & 1 & $\mathrm{ZcZ} 17^{\mathrm{d}}$ & ZcZ40 \\
\hline Total samples & $\ldots$ & $\ldots$ & 46 & 29 & 21 & 9 & 9 \\
\hline
\end{tabular}

${ }^{\mathrm{a}} \mathrm{RT}-\mathrm{PCR}=$ reverse transcription-polymerase chain reaction, $\mathrm{BCMV}=$ Bean common mosaic virus, and $\mathrm{BCMNV}=$ Bean common mosaic necrosis virus.

b NA $=$ not applicable and $\mathrm{NC}=$ not cloned.

${ }^{\mathrm{c}}$ Number of the sample that tested positive for at least one viral species (samples that tested negative for either of the two viruses were not listed).

d Sequences deposited in GenBank with the following accession numbers: AF328760 (CpP52), AF328759 (ChGM 24), AF328758 (DrD 5), AF328757 (Gn A1), AF328755 (GnR9), AF328756 (GnR 11), AF328754 (SpT2), AF328751 (TlT 93), AF328752 (ZcF 8), and AF328753 (ZcZ 17). 
Hidalgo, Jalisco, Mexico, and Quintana Roo. In this initial survey, BCMV was more abundant $(63 \%$ of the samples positive), than BCMNV (45\% of the samples positive), and their geographical distributions were somewhat different (Fig. 1). In the humid eastern tropics of Mexico (Campeche, Chiapas, Puebla, part of San Luis Potosí, Tabasco, and Veracruz), BCMNV was more frequent. In two states (Chihuahua and Guanajuato) located in the semiarid highlands and semihumid temperate midlands, respectively, BCMV was predominant. In three states (Durango, Tlaxcala, and Zacatecas) encompassing semiarid highlands, both viruses were found in single (5 out of 11 samples) and mixed infections (6 out of 11 samples).

Nucleotide sequence analyses and comparisons. Eighteen nucleotide sequences of both viral species (nine of each), comprising most of the $\mathrm{CP}$ gene (35 nucleotides less than the full $\mathrm{CP}$ gene), were obtained after RT-PCR amplification reactions with the appropriate primers and cloning of the amplified products (Figs. 2 and 3). Each of the nucleotide sequences of the Mexican isolates was compared with those in GenBank using the BLAST algorithm and grouped according to pathogenicity groups (12). The results obtained confirmed the diagnosis achieved through RT-PCR. Thus, isolates ChGM24 and $\mathrm{ChC} 25$ (from Chihuahua), DrVO4, and DrD37 (from Durango), GnA1, GnR9, and GnR11 (from Guanajuato), T1T93 (from Tlaxcala), and ZcZ17 (from Zacatecas) had higher identities (between 73 and 95\%) with the reported BCMV sequences. Of all these, the sequences of isolates ChGM24 and TIT93 were most similar to previously characterized isolates from pathogroup II. All other BCMV isolates were most similar to pathogroup I isolates. On the other hand, isolates PbP84 (from Puebla), CmH8 (from Campeche), CpP52 (from Chiapas), DrD5 (from Durango), SpT2 (from San Luis Potosí), TbH22 (from Tabasco), VrC1 (from Veracruz), and ZcF8 and ZcZ40 (from Zacatecas) had a high identity (95 to 97\%) to BCMNV nucleotide sequences from pathogroup VI (Fig. 4).

\section{DISCUSSION}

The primers reported here specifically differentiated two viral species in Mexico: BCMV and BCMNV. The specificity of these primers was confirmed through nucleotide sequence analysis. These primers will be useful for rapidly screening bean germ plasm where seed contamination by isolates of the two viral species occurs. In contrast, Klein reported the identification of several pathogenicity groups of BCMV through inoculation of an extensive set of differential $P$. vulgaris cultivars and addressed the inability of the procedure to deal efficiently with a large number of cultures and with the high incidence of mixed infections (16). Similar studies of the presence of BCMNV in Mexico were limited due to a lack of a thorough screening method of the germ plasm.

As shown here, these primers were useful tools to study the distribution of BCMV and BCMNV in Mexico. Indeed, BCMNV was distributed more evenly throughout Mexico, whereas BCMV species were collected mainly from the central highland states (Fig. 1). One possible explanation for this could be the bean cultivars that are preferentially grown in the different regions. Many bean cultivars are grown in the major producer states (Zacatecas, Durango, Chihuahua, and Sinaloa; 3), the semiarid highland. In the central part of the country (Guanajuato, Querétaro, and Tlaxcala), Flor de Mayo, Azufrado, Peruano, Flor de Junio, and Bayo are produced. In the eastern part, black cultivars mostly are grown (Negro Jamapa, Arbolito, Negro Tacaná, and Veracruzano Negro Huasteco; 23).

A question arises as to why two other states, not on the coast but in the northern part of the country (Durango and Zacatecas), and one in the center (Tlaxcala) have BCMNV. The explanation might be that those states are producers, distributors, and consumers of many bean cultivars (5); as a consequence, both viral species are detected. Genotypic diversity of serotypes A and B (now viral species BCMNV and BCMV, respectively) in different regions has suggested before that host population imposes a strong selective force for pathotypic variation (26). In contrast to the black bean cultivars grown near the coast, the 'White' and 'Pinto' cultivars mainly are produced in Chihuahua (north) whereas, in Guanajuato (central Mexico), 'Flor de Mayo' is the one most commonly grown and consumed. In these two states, no

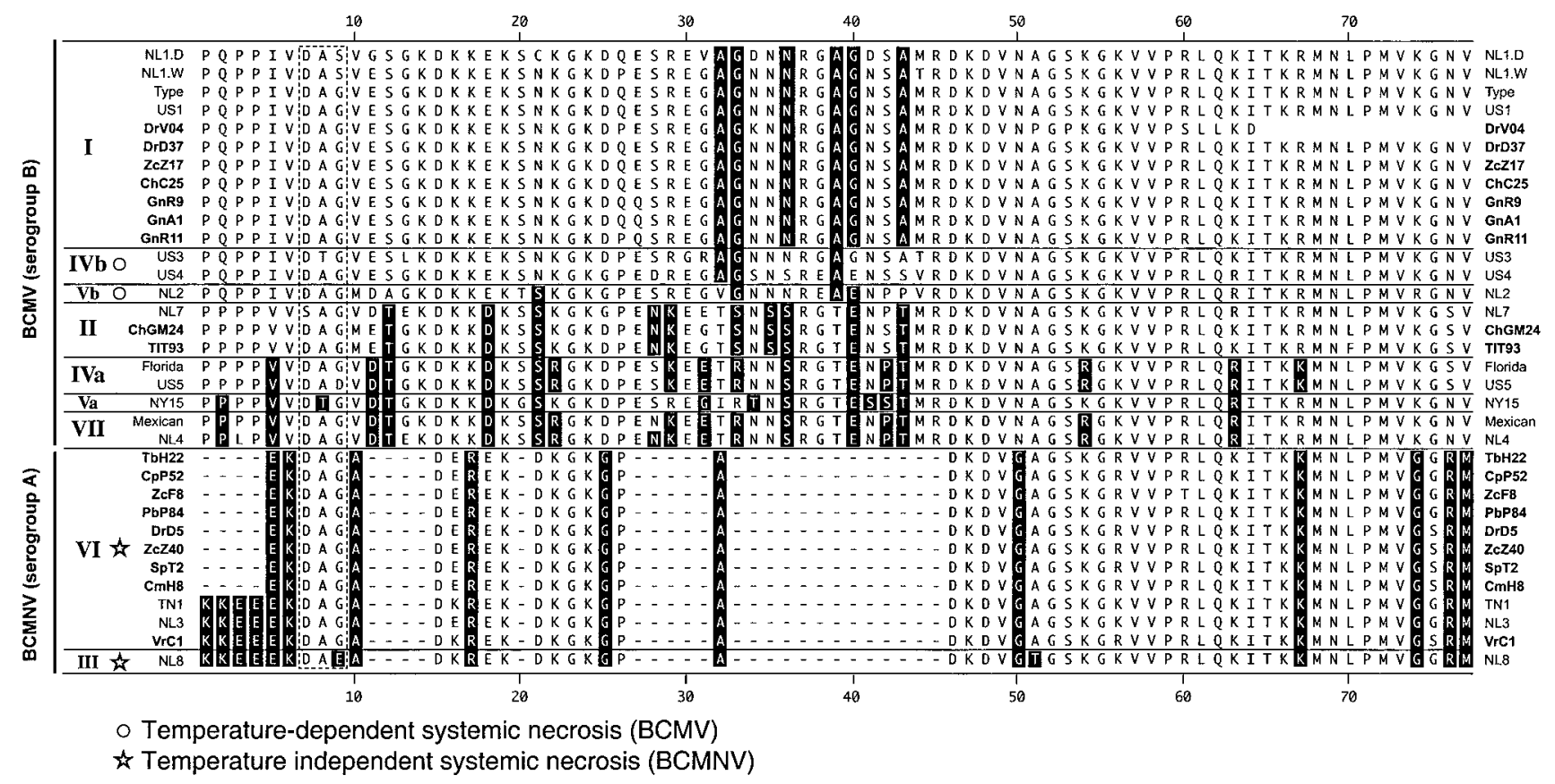

Fig. 4. Alignment of the 77 amino acids for Bean common mosaic virus (BCMV) and 50 or 54 for Bean common mosaic necrosis virus (BCMNV) at the amino terminus of the capsid protein (CP). The alignment started six amino acids before the putative aphid transmissibility DAG motif (left box). The sequences from GenBank were grouped according to their sero- and pathogenicity group (26) and are shown in roman letters. The names of the Mexican sequences reported here are bolded. All other sequences were extracted from the GenBank and translated into amino acid sequences. Light gray areas encase some of the amino acids which seem to be conserved within a pathogroup. 
BCMNV has been detected so far. It would be interesting to study which resistance genes ( $I$ and the $b c$ gene series) are present in all Mexican bean cultivars to investigate the role of host resistance on the selection of the viral species.

The alignment of some reported BCMVand BCMNV-derived amino acid sequences of the $\mathrm{CP}$ at the amino terminus (a more variable region than the carboxyl terminus) gave a preliminary indication of the pathogroups that might be present in Mexico. However, extensive biological assays on differential bean cultivars (16) need to be carried out to confirm this observation. The distribution of BCMV and BCMNV in Mexico hereby reported will be useful for breeders to incorporate virus resistance into bean cultivars where any or both of the two viral species occur.

\section{ACKNOWLEDGMENTS}

We thank J. C. Noa and J. L. Quiroz for their help on sample collection; L. Ramírez for technical help; A. R. Razo and her staff for greenhouse work; D. González-de-León for his critical review of this manuscript; and reviewer no. 1 for constructive criticisms.

\section{LITERATURE CITED}

1. Alemán-Verdaguer, M., Goudou-Urbino, C., Dubern, J., Beachy, R. N., and Fauquet, C. 1997. Analysis of the sequence diversity of the P1, HC, P3, NIb and CP genomic regions of several yam mosaic potyvirus isolates: implications for the intraspecies molecular diversity of potyviruses. J. Gen. Virol. 78:12531264.

2. Altschul, S. F., Madden, T. L., Schaffer, A. A., Zhang, J., Zhang, Z., Miller, W., and Lipman, D. J. 1997. Gapped BLAST and PSI-BLAST: a new generation of protein database search programs. Nucleic Acids Res. 25:3389-3402.

3. Anuario del Centro de Estadística Agropecuaria. 2000. Secretaría de Agricultura Ganaderia Desarrollo Rural Pesca y Alimentación, D.F. Mexico.

4. Berger, P. H., Wyatt, S. D., Shiel, P. J., Silbernagel, M. J., Druffel, K., and Mink, G. I. 1997. Phylogenetic analysis of the Potyviridae with emphasis on legume-infecting potyviruses. Arch. Virol. 142:1979-1999.

5. Castellanos, J. Z., Guzmán-Maldonado, H., Jiménez, A., Mejía, C., Muñoz-Ramos, J. J.,
Hoyos, G., López-Salinas, E., GonzálezEguiarte, D., Salinas-Pérez, R., GonzálezAcuña, J., Muñoz-Villalobos, J. A., Fernández-Hernández, P., and Cáceres, B. 1997. Hábitos preferenciales de los consumidores de frijol común (Phaseolus vulgaris L.) en Mexico. Arch. Latinoam. Nutr. 47:163-167.

6. Collmer, C. W., Marston, M. F., Taylor, J. C., and Jahn, M. 2000. The $I$ gene of bean: a dosage-dependent allele conferring extreme resistance, hypersensitive resistance, or spreading vascular necrosis in response to the potyvirus bean common mosaic virus. Mol. Plant-Microbe Interact. 13:1266-1270.

7. Díaz-Plaza, R., Téliz, O. D., and MuñozOrozco, A. 1992. Efecto de las enfermedades en frijol de temporal en la Mixteca Poblana. Rev. Mex. Fitopatol. 9:21-30.

8. Dijkstra, J., and Khan, J. A. 1992. A proposal for a bean common mosaic subgroup of potyviruses. Arch. Virol. Suppl. 5:389-395.

9. Dougherty, W. G., and Carrington, J. C. 1988. Expression and function of potyviral gene products. Annu. Rev. Phytopathol. 26:123143.

10. Fang, G. W., Allison, R. F., Zambolim, E. M., Maxwell, D. P., and Gilbertson, R. L. 1995. The complete nucleotide sequence and genome organization of bean common mosaic virus (NL3 strain). Virus Res. 39:13-23.

11. Flores-Estévez, N., Silva-Rosales, L., and Acosta-Gallegos, J. 2000. First report of bean common mosaic necrotic virus infecting bean plants in Aguascalientes and Veracruz. Plant Dis. 84:923.

12. Hall, R. ed. 1991. Compendium of Bean Diseases. American Phytopathological Society Press, St. Paul, MN.

13. Jeanmougin, F., Thompson, J. D., Gouy, M., Higgins, D. G., and Gibson, T. J. 1998. Multiple sequence alignment with Clustal X. Trends Biochem. Sci. 23:403-405.

14. Jiménez García, E., and Nelson, M. R. 1994. Los virus del frijol en las áreas agrícolas de Sonora. Instituto Nacional de Investigaciones Forestales y Agropecuarias, Hermosillo, Mexico.

15. Kelly, J. D. 1997. A review of varietal response to bean common mosaic potyvirus in Phaseolus vulgaris. Plant Var. Seeds 10:1-6.

16. Klein, R. E. 1992. Pathogenicity groups of Bean common mosaic virus in the USDA Phaseolus germ plasm collection. Plant Dis. 76:1263-1265.

17. Lindbo, J. A., Silva-Rosales, L., Proebsting, W. M., and Dougherty, W. G. 1993. Induction of a highly specific antiviral state in transgenic plants: implications for regulation of gene expression and virus resistance. Plant Cell 5:1749-1759.

18. López-Salinas, E., Durán-Prado, A., BecerraLeor, E. N., Esqueda-Esquivel, V. A., and Cano-Reyes, O. 1994. Manual de producción de frijol en el estado de Veracruz. Instituto Nacional de Investigaciones Forestales y Agropecuarias, SARH, Cotaxtla, Mexico.

19. McKern, N. M. 1992. Isolates of bean common mosaic virus comprising two distinct potyviruses. Phytopathology 82:923-929.

20. Mink, G. I., and Silbernagel, M. J. 1992. Serological and biological relationships among viruses in the bean common mosaic virus subgroup. Arch. Virol. Suppl. 5:397406.

21. Montes-Rivera, R., and Arévalo-Valenzuela, A. 1985. Guía para cultivar frijol de riego en el centro y sur de Guanajuato. Instituto Nacional de Investigaciones Forestales y Agropecuarias, SARH, Celaya, Mexico.

22. Morales, F. J. 1998. Present status of controlling Bean Common Mosaic virus. Pages 524533 in: Plant Virus Disease Control. A. Hadidi, R. K. Khetarpal, and H. Koganezawa, eds. American Phytopathological Society Press, St. Paul, MN.

23. Rosales-Serna, R., Acosta-Gallegos, J. A., Muruaga-Martínez, J. S., Esquivel-Esquivel, G. y Pérez-Herrera, P. 2002. Catálogo de variedades mejoradas de frijol del Instituto Nacional de Investigaciones Forestales, Agrícolas y Pecuarias, SAGARPA, Mexico. In press

24. Ruiz-Castro, S., and Silva-Rosales, L. 1997. Use of RT-PCR for papaya ringspotyvirus detection in papaya (Carica papaya) plants from Veracruz, Tabasco and Chiapas. Rev. Mex. Fitopatol. 15:83-87.

25. SAGAR. Centro de Estadística Agropecuaria 2000.

26. Saiz, M., Castro, S., Blas, C., and J., R. 1994 Serotype-specific detection of bean common mosaic potyvirus in bean leaf and seed tissue by enzymatic amplification. J. Virol. Methods 50:145-154.

27. Spence, N. J., and Walkey, D. G. A. 1995 Variation for pathogenicity among isolates of bean common mosaic virus in Africa and a reinterpretation of the genetic relationship between cultivars of Phaseolus vulgaris and pathotypes of BCMV. Plant Pathol. 44:527546.

28. Vetten, H. J., Lesemann, D. E., and Maiss, E. 1992. Serotype A and B strains of bean common mosaic virus are two distinct potyviruses. Arch. Virol. Suppl. 5:415-431. 